\title{
Effect of feeding and housing systems on rumen properties and plasma metabolite stress indicators in autochthonous Spanish Ojalada sheep
}

\author{
José A. Miguel, José L. Calvo, Jesús Ciria, and Begoña Asenjo \\ Área de Producción Animal, Escuela de Ingenierías Agrarias de Soria, Universidad de Valladolid. Campus \\ Universitario s/n, 42004-Soria, Spain.
}

\begin{abstract}
J.A. Miguel, J.L. Calvo, J. Ciria, and B. Asenjo. 2015. Effect of feeding and housing systems on rumen properties and plasma metabolite stress indicators in autochthonous Spanish Ojalada sheep. Cien. Inv. Agr. 42(1): 65-73. To rear lambs of the Ojalada breed, fed exclusively on mothers' milk until 5 weeks, three feeding systems were compared: a) ewes kept indoors and fed chopped straw plus concentrate (IND $+\mathrm{CH}+\mathrm{C})$, total mixed ration (TMR); b) ewes kept indoors and fed whole straw in the form of large bales plus concentrate $(\mathrm{IND}+\mathrm{W}+\mathrm{C})$, $\mathrm{TMR}$; and c) free-range grazing plus concentrate $(\mathrm{GR}+\mathrm{C}$; control group). Parameters related to ruminal fermentation $\left(\mathrm{pH}, \mathrm{NH}_{3}-\mathrm{N}\right.$ concentration and proportion of volatile fatty acids (VFAs)) in 40 sheep during a production cycle were monitored. The plasma concentrations of stressrelated metabolites (i.e., glucose, lactate, phosphate, creatine kinase (CK), cortisol and nonesterified fatty acids (NEFAs)) during a production cycle and in 10 sheep during lactation (5 weeks) were tested. The sheep fed a whole forage ration $(\mathrm{IND}+\mathrm{W}+\mathrm{C}$ and $\mathrm{GR}+\mathrm{C}$ treatment group) had higher concentrations of $\mathrm{NH}_{3}-\mathrm{N}$ and total VFAs, but no differences were found in the acetate/propionate ratio in sheep in the $\mathrm{IND}+\mathrm{CH}+\mathrm{C}$ treatment group compared to the control group. When analyzing plasma metabolites, we found that during the entire production cycle, grazing sheep had higher concentrations of glucose and cortisol. The concentration of NEFAs was also higher for the $\mathrm{GR}+\mathrm{C}$ treatment group when evaluated during lactation. Thus, we concluded that the ration particle size for sheep fed a TMR influences the concentration of $\mathrm{NH}_{3}-\mathrm{N}$ and VFAs in the rumen. Keeping the sheep indoors during the production cycle and during lactation did not increase the plasma levels of the evaluated stress indicators.
\end{abstract}

Key words: Barley straw, ewe, grazing, local Spanish breed.

\section{Introduction}

The Ojalada breed of sheep is reared primarily in the central and south-western zones of the region of Soria in North-Central Spain. It differs from other breeds because of its peculiar mor-

Received November 6, 2014. Accepted March 13, 2015 Corresponding author: jangel@agro.uva.es phological characteristics (half-fine white fleece with centrifugal black pigmentation). This breed is studied less than other autochthonous Spanish breeds. Lambs from the Ojalada breed are raised without having been separated by sex and are fed exclusively on mothers' milk until five weeks.

The two primary expenses in traditional systems of sheep husbandry include dietary supplements 
and labor. Because these factors directly affect lamb health and quality of the product, sheep raisers are often burdened with high amounts of difficult labor, which can decrease the raisers' quality of life. To minimize cost and labor demands while maximizing quality, sheep raisers use a management strategy based on the use of agrarian subproducts. For example, a TMR diet helps achieve automation of feeding at a minimum cost. TMR diets are composed of only one type of feed and can be given to animals kept indoors; many studies have been conducted (Miguel et al., 2011) to evaluate the productive endpoints with the goal of a reduced dependence on grazing and labor.

For ruminant feeding, ingested small particle has been linked to the incidence of digestive disorders, such as decreased $\mathrm{pH}$ in the rumen. In theory, physically effective fiber is a measurement for the ability of an ingredient to stimulate rumination and saliva production, thereby increasing the ruminal pH (Yang and Beauchemin, 2005). Some authors (Calberry et al., 2003) have found a positive relationship between the particle size and the ruminal $\mathrm{pH}$, but others have not found such a relationship in their studies (Einarson et al., 2004).

In the field of animal welfare, intensive production systems that make use of space-restricted accommodations cause frustration and stress to the animals because the animals cannot behave as the species normally would (Carlstead, 1996). These behaviors are related to obsessive-compulsive disorders and could be related to states of frustration, anxiety and depression (Hedlund and Sutcliffe, 2007).

A breed's physiological response has been used to determine the degree of stress resulting from handling, transport and slaughter. Elevated plasma levels of cortisol (Sevi et al., 2001), lactate and glucose (Kannan et al., 2000) are associated with stress. Similarly, other authors (Kannan et al., 2007) have suggested that the temperament and behavior of animals can cause variability in plasma concentration of CK. Increased plasma levels of NEFAs have also been cited by some researchers as a sign of stress (Kannan et al., 2002).

After analyzing and characterizing the effect of feeding systems on the live weight, reproductive performance, milk yield, milk composition and growth of lambs in native Spanish Ojalada sheep (Miguel et al., 2011), the objective of this study was to analyze and characterize the effects of management and feeding systems on various ruminal parameters (molar concentration of volatile fatty acids, $\mathrm{NH}_{3}-\mathrm{N}$ content and $\mathrm{pH}$ ) and the plasma concentration of several metabolites associated with stress (glucose, lactate, cortisol, CK and NEFAs) in this autochthonous Spanish breed.

\section{Materials and methods}

\section{Location and animal resources}

The study was performed at the Campo Agropecuario de San Esteban de Gormaz (Diputación Provincial de Soria) located $70 \mathrm{~km}$ from Soria, Spain $\left(41^{\circ} 34^{\prime} \mathrm{N}, 3^{\circ} 12^{\prime} \mathrm{W}\right.$ and 879 masl). At these installations, work has been ongoing for 30 years on the characterization, conservation and genetic improvement of the native Ojalada breed, and a system involving three live births every two years (per ewe) has been employed.

The study was conducted throughout a productive cycle (breeding at the end of the lactation period). To this end, 120 ewes of the Ojalada breed between the ages of 4 and 6 years with a $61.8 \pm 8.2 \mathrm{~kg}$ live weight, body condition score of $2.92 \pm 0.05$ and the same production of milk from the previous lactation were distributed randomly into three groups (40 ewes per group). No hormonal treatment was used for the induction and synchronization of periods of heat. During the breeding season (winter), two males were added to each group, and they remained 
with the ewes for 45 days (for a possibility of breeding in two heat periods). The endpoints were recorded throughout the entire productive cycle until the end of the lactation period in the month of August.

During the five weeks of lactation, a weekly evaluation was performed for both the quantity and chemical composition of the milk. Milk was sampled from 10 randomly chosen single-birth ewes from each group. To accomplish this evaluation, the lambs were separated from their mothers early in the morning. The ewes were injected with $5 \mathrm{IU}$ of oxytocin and milked mechanically followed by a second more complete milking by hand. Four hours after the first injection of oxytocin, the operation was repeated with the same dose of oxytocin, and the amount of milk obtained from this second milking was measured.

\section{Feeding and handling}

With regard to feeding and handling systems, the animals were randomly allocated to three pens ( $n=40$ per treatment) as follows:

a) Ewes were permanently kept indoors $\left(1.5 \mathrm{~m}^{2}\right.$ per ewe with access to an $80 \mathrm{~m}^{2}$ outdoor pen) during the experimental period (IND $+\mathrm{CH}+\mathrm{C}$ ). Animals were provided with a TMR based on chopped barley straw (short fiber; $5 \mathrm{~mm}$ ) mixed with concentrate, which was distributed mechanically and administered ad libitum.

b) Ewes were permanently kept indoors $\left(1.5 \mathrm{~m}^{2}\right.$ per ewe with access to an $80 \mathrm{~m}^{2}$ outdoor pen) during the experimental period (IND $+\mathrm{W}+\mathrm{C})$. Animals were provided with a TMR based on whole barley straw (long fiber) from large bales (approximately $450 \mathrm{~kg}$ ) mixed with concentrate using an industrial mixer and administered ad libitum.

c) The control group was subjected to traditional management in which ewes were let out to graze during the day with supplements provided only during last third of gestation, during lactation and when adverse weather kept them from going outdoors $(\mathrm{GR}+\mathrm{C})$. The flock was managed under a year-round grazing system involving Mediterranean grassland and forest-shrub pastures in the summer, autumn and winter (Casasús et al., 2007) as well as permanent valley pastures in the spring and autumn (30 ewes/ha). The pasture was composed of $24 \%$ legumes (mainly Trifolium repens), $65 \%$ grass (the main species were Festuca arundinacea, F. pratensis, Poa pratensis, Lolium perenne and Dactylis glomerata) and $11 \%$ other species (mainly Rumex acetosa and Ranunculus bulbosus). Ten representative herb samples (in 10 quadrants) were collected at monthly intervals. Herbage dry matter (DM) $(202.4 \pm 56.2 \mathrm{~kg}$ DM $\mathrm{ha}^{-1}$ ) was determined by heating it to $60{ }^{\circ} \mathrm{C}$ until its weight was constant, and crude protein (CP) $\left(212.5 \pm 11.7 \mathrm{~g} \mathrm{CP} \mathrm{kg} \mathrm{DM}^{-1}\right)$ was determined by the Dumas procedure according to the AOAC method (1999). Neutral detergent fiber (NDF) $\left(510.8 \pm 23.3 \mathrm{~g} \mathrm{NDF} \mathrm{kg} \mathrm{DM}^{-1}\right)$ was analyzed by the method of Van Soest et al. (1991).

Because one of the objectives of the experiment was to use a type of raw material that would not increase feeding costs, the principal component of the feed was barley straw in its natural state (918 $\mathrm{g} \mathrm{DM} \mathrm{kg}^{-1}, 38 \mathrm{~g} \mathrm{CP} \mathrm{kg} \mathrm{DM}^{-1}$ and $772 \mathrm{~g} \mathrm{NDF}^{-1}$ $\mathrm{kg} \mathrm{DM}^{-1}$ ), which was chopped for the IND $+\mathrm{CH}+\mathrm{C}$ group and left whole for the IND $+\mathrm{W}+\mathrm{C}$ group. As a complement to the straw, concentrate was added during last third of gestation and lactation. The same type of concentrate was used for both groups, and it was mixed with the straw so that the animals could not separate it. The composition of this concentrate (Table 1) and the proportion of straw varied according to the productive stage as follows: a) during maintenance and the first two thirds of gestation, the proportion was $80 \%$ barley straw and $20 \%$ concentrate; and b) during the last third of gestation and lactation, the proportion was $40 \%$ barley straw and $60 \%$ concentrate. The proportion of straw used at each production stage was used by the distributor of large bales. 
Table 1. Ingredients, chemical composition and nutritional value of the concentrate based on productive phase (all the data on fed basis).

\begin{tabular}{|c|c|c|}
\hline & $\begin{array}{l}\text { Maintenance and } \\
\text { first two thirds of } \\
\text { gestation }\end{array}$ & $\begin{array}{l}\text { Last third of } \\
\text { gestation and } \\
\text { lactation }\end{array}$ \\
\hline \multicolumn{3}{|l|}{ Ingredients $\left(\mathrm{g} \mathrm{kg}^{-1}\right)$} \\
\hline Barley & 485 & 460 \\
\hline $\begin{array}{l}\text { Sunflower flour } \\
30 \%\end{array}$ & 300 & 300 \\
\hline $\mathrm{DDGS}^{1}$ corn & 1.0 & - \\
\hline DDGS $^{1}$ sorghum & - & 150 \\
\hline Cane molasses & 40 & 40 \\
\hline Salt & 5 & 5 \\
\hline $\begin{array}{l}\text { Dicalcium } \\
\text { phosphate }\end{array}$ & 10 & 4 \\
\hline $\begin{array}{l}\text { Calcium } \\
\text { carbonate }\end{array}$ & - & 11 \\
\hline Calcium soap & - & 20 \\
\hline $\begin{array}{l}\text { Sodium } \\
\text { bicarbonate }\end{array}$ & 5 & 5 \\
\hline $\begin{array}{l}\text { Magnesium } \\
\text { oxide }\end{array}$ & 2 & 2 \\
\hline $\begin{array}{l}\text { Mineral-vitamin } \\
\operatorname{mix}^{2}\end{array}$ & 3 & 3 \\
\hline \multicolumn{3}{|l|}{$\begin{array}{l}\text { Chemical } \\
\text { composition } \\
\left(\mathrm{g} \mathrm{kg}^{-1}\right)\end{array}$} \\
\hline Dry matter & 894.1 & 898.1 \\
\hline Organic matter & 956.8 & 958.7 \\
\hline Crude protein & 184.7 & 190.5 \\
\hline $\begin{array}{l}\text { Neutral- } \\
\text { detergent fiber }\end{array}$ & 269.3 & 247.7 \\
\hline \multicolumn{3}{|l|}{ Nutritional value } \\
\hline $\begin{array}{l}\text { Energy }\left(\mathrm{UFL}^{3}\right. \\
\left.\mathrm{kg}^{-1}\right)\end{array}$ & 0.87 & 0.84 \\
\hline $\begin{array}{l}\text { Protein }\left(\mathrm{g} \text { PDIN }^{3}\right. \\
\mathrm{kg}^{-1} \text { ) }\end{array}$ & 123.3 & 121.5 \\
\hline $\begin{array}{l}\text { Protein }\left(\mathrm{g} \mathrm{PDIE}^{3}\right. \\
\left.\mathrm{kg}^{-1}\right)\end{array}$ & 99.2 & 97.1 \\
\hline
\end{tabular}

${ }^{1}$ DDGS: Dried Distillers Grains with Solubles.

${ }^{2}$ Mineral-vitamin mix provided (per $\mathrm{kg}$ of premix): $\mathrm{Zn}$, $5000 \mathrm{mg}$; Mn, $5000 \mathrm{mg}$; Fe, $1750 \mathrm{mg}$; Co, $100 \mathrm{mg}$; I, $70 \mathrm{mg}$; Se, 25 mg; vitamin A, 600,000 IU; vitamin D3, 120,000 IU; vitamin E, 2,000 mg.

${ }^{3}$ UFL, 7.11 MJ net energy for lactation; PDIN, protein digestible at the level of intestine when nitrogen is limiting; PDIE, protein digestible at the level of intestine when energy is limiting as estimated from INRA (2007).
The average consumption of food was measured only in the groups permanently kept indoors. Specifically, the food was weighed when it was supplied in the IND $+\mathrm{CH}+\mathrm{C}$ group, and the weight of the large bales was known in the IND $+\mathrm{W}+\mathrm{C}$ group.

\section{Measurements and analytical methods}

Once per month during the production cycle, coinciding with weight control, as well as once per week during the lactation period (five weeks), coinciding with the control of milk production, (Miguel et al., 2011), $10 \mathrm{~mL}$ of blood was collected from the jugular vein of the sheep and placed in a heparin tube. The blood was stored at $4{ }^{\circ} \mathrm{C}$ until centrifugation to obtain the plasma, and plasma was then aliquoted into Eppendorf tubes and frozen at $-20^{\circ} \mathrm{C}$ until it was thawed for further experimentation. Plasma glucose, lactate, cortisol, NEFAs and CK activity were analyzed according to the methods of Kannan et al. (2000, 2002).

The rumen fluid samples were collected using a stomach tube for the VFA, $\mathrm{pH}$ and $\mathrm{NH}_{3}-\mathrm{N}$ determinations. The $\mathrm{pH}$ values of the rumen fluid, which may be related to the VFA concentrations, were determined with the aid of a $\mathrm{pH}$ meter. After the $\mathrm{pH}$ measurement, the rumen fluid was strained through 8 layers of cheesecloth. The filtrate $(150 \mathrm{~mL})$ was acidified with $7.2 \mathrm{~N} \mathrm{H}_{2} \mathrm{SO}_{4}(1 \%$ per volume) and frozen. The samples were later thawed in a refrigerator overnight, and $10 \mathrm{~mL}$ portions were centrifuged at $10,000 \times \mathrm{g}$ for $10 \mathrm{~min}$. The supernatant was used for ammonia analysis according to a modified procedure of Broderick and Kang (1980). The VFA content was analyzed using a gas chromatographer (Hewlett-Packard, Avondale, PA, Model 5890 series II) fitted with a Supelco packed glass column $(2 \mathrm{~m} \times 4 \mathrm{~mm}, 15 \%$ SP-1220, 1\% $\mathrm{H}_{3} \mathrm{PO}_{4}$ and 100/120 Chromosorb) (Goetsch and Galyean, 1983). 


\section{Statistical analyses}

The data were analyzed using the generalized linear model procedure of SAS (SAS Institute Inc., SAS Campus Drive, Cary, North Carolina, USA) according to the following model:

$$
y_{i j}=\mu+\alpha_{i}+\varepsilon_{i j}
$$

where $y_{i j}$ is the dependent variable; $\mu$ is the overall mean; $\alpha_{i}$ is the treatment effect; and $\varepsilon_{i j}$ is the residual error.

When significant differences were detected with the ANOVA analysis, the differences between the mean values of each treatment were analyzed by Dunnett's test $(\alpha=0.05)$.

\section{Results}

\section{Ruminal parameters}

As shown in Table 2, the rumen in the sheep in the $\mathrm{IND}+\mathrm{CH}+\mathrm{C}$ treatment group (with a smaller ration particle size $)$ had a lower $\mathrm{pH}(\mathrm{P}=0.006)$ and a lower content of $\mathrm{NH}_{3}-\mathrm{N}(\mathrm{P}=0.025)$ compared to the other groups, and there were no differences among treatment groups for total VFAs $(\mathrm{P}=0.120)$.

As expected, acetate, propionate and butyrate were the VFAs found in greatest proportion in the rumen in the three treatments. No differences were found among treatments for any of the VFAs except in the case of the GR $+\mathrm{C}$ treatment group, where isovalerate was found to be significantly higher than in the other two treatment groups $(\mathrm{P}=0.023)$.

No differences were found in the acetate/propionate ratio among treatment groups $(\mathrm{P}=0.568)$.

\section{Plasma metabolites}

Levels of glucose, lactate and CK were higher in all three treatments groups during the lactation period compared to the entire production cycle (Tables 3 and 4).

Analysis of the parameters indicative of stress in the blood samples during the entire experimental

Table 2. Effect of treatment on ruminal parameters.

\begin{tabular}{|c|c|c|c|c|c|}
\hline & \multicolumn{3}{|c|}{ Treatment $(\mathrm{n}=40 \text { per treatment })^{1}$} & \multirow[b]{2}{*}{$\mathrm{SEM}^{2}$} & \multirow[b]{2}{*}{$P$-value } \\
\hline & $\mathrm{IND}+\mathrm{CH}+\mathrm{C}$ & $\mathrm{IND}+\mathrm{W}+\mathrm{C}$ & $\mathrm{GR}+\mathrm{C}$ & & \\
\hline Ruminal pH & $6.24 b$ & $6.50 \mathrm{a}$ & $6.48 \mathrm{a}$ & 0.06 & 0.006 \\
\hline $\mathrm{NH}_{3}-\mathrm{N}\left(\mathrm{mg} 100 \mathrm{~mL}^{-1}\right)$ & $9.15 b$ & $11.86 \mathrm{a}$ & $12.43 \mathrm{a}$ & 0.16 & 0.025 \\
\hline Total VFAs (mmol L-1) & 24.62 & 24.17 & 24.14 & 2.23 & 0.120 \\
\hline \multicolumn{6}{|c|}{ Molar proportion of VFAs (\%) } \\
\hline Acetate & 63.8 & 62.3 & 62.1 & 0.21 & 0.282 \\
\hline Propionate & 17.5 & 16.3 & 16.7 & 0.23 & 0.361 \\
\hline Butyrate & 6.8 & 7.4 & 6.7 & 0.17 & 0.255 \\
\hline Isobutyrate & 2.3 & 2.4 & 2.8 & 0.13 & 0.856 \\
\hline Valerate & 1.3 & 1.4 & 1.6 & 0.12 & 0.784 \\
\hline Isovalerate & $2.7 \mathrm{~b}$ & $2.9 \mathrm{~b}$ & $3.2 \mathrm{a}$ & 0.24 & 0.023 \\
\hline Acetate/propionate & 3.63 & 3.82 & 3.72 & 0.47 & 0.568 \\
\hline
\end{tabular}

${ }^{1}$ Treatments: $\mathrm{IND}+\mathrm{CH}+\mathrm{C}$, chopped barley straw + concentrate; IND $+\mathrm{W}+\mathrm{C}$, whole barley straw + concentrate (large bales); $\mathrm{GR}+\mathrm{C}$, grazing + concentrate

${ }^{2} \mathrm{SEM}$ : Standard error of least-squares means

Different letters in the same row indicate significant differences among treatments (Dunnett's test, $\alpha=0.05$ ) 
period (Table 3) revealed a higher concentration of glucose $(\mathrm{P}=0.015)$ and cortisol $(\mathrm{P}=0.002)$ in sheep in the $\mathrm{GR}+\mathrm{C}$ treatment group, which grazed as the traditional food system.

When analyzing the results of the lactation period (Table 4), we observed a higher NEFA content $(\mathrm{P}=0.036)$ in the IND $+\mathrm{W}+\mathrm{C}$ and $\mathrm{GR}+\mathrm{C}$ treatment groups compared to the $\mathrm{IND}+\mathrm{CH}+\mathrm{C}$ treatment group. We did not observe differences in any other parameters among treatment groups $(\mathrm{P}=0.743 ; \mathrm{P}=0.851)$.

\section{Discussion}

\section{Ruminal parameters}

In all three treatments, the $\mathrm{pH}$ values of the rumen were between 6.1 and 6.8 , which is within the optimal physiological range as suggested by Van Soest (1994). In all three cases, the concentration of $\mathrm{NH}_{3}-\mathrm{N}$ in the ruminal fluid was greater than 5 $\mathrm{mg} \mathrm{dL} \mathrm{L}^{-1}$, which is the minimum value required for optimal growth of microorganisms in the rumen.

Similar to Asadi et al. (2009), we observed a lower $\mathrm{pH}$ in rumen of sheep fed chopped forage versus whole forage, which may be due to faster ingestion of food with a smaller particle size, thus decreasing the production of saliva. Less saliva leads to less buffer capacity to maintain $\mathrm{pH}$ within the optimal range. In contrast, Pereira et al. (2009) did not find differences in ruminal $\mathrm{pH}$ between goats fed $5 \mathrm{~mm}$ chopped forage versus whole forage.

Although our study showed a $\mathrm{NH}_{3}-\mathrm{N}$ higher content in treatment groups fed with larger particle sizes (whole and grazing straw), Asadi et al. (2009) found no differences when comparing sheep diets with two different particle sizes. Other researchers have found that different concentrations of $\mathrm{NH}_{3}-\mathrm{H}$ in the rumen are related more to the type of concentrate used in the diet than particle size (Azizi-Shotorkhoft et al., 2013).

Table 3. Effect of treatment on plasma metabolites throughout the productive cycle.

\begin{tabular}{|c|c|c|c|c|c|}
\hline & \multicolumn{3}{|c|}{ Treatment $(n=40 \text { per treatment })^{1}$} & \multirow[b]{2}{*}{$\mathrm{SEM}^{2}$} & \multirow[b]{2}{*}{$P$-value } \\
\hline & $\mathrm{IND}+\mathrm{CH}+\mathrm{C}$ & $\mathrm{IND}+\mathrm{W}+\mathrm{C}$ & $\mathrm{GR}+\mathrm{C}$ & & \\
\hline Glucose $\left(\mathrm{mg} \mathrm{dL}^{-1}\right)$ & $60.83 \mathrm{~b}$ & $61.01 \mathrm{~b}$ & $64.45 \mathrm{a}$ & 0.71 & 0.015 \\
\hline Lactate $\left(\mathrm{mg} \mathrm{dL}^{-1}\right)$ & 39.99 & 36.92 & 37.04 & 1.97 & 0.689 \\
\hline $\mathrm{CK}\left(\mathrm{U} \mathrm{L}^{-1}\right)$ & 163.59 & 152.78 & 190.14 & 6.45 & 0.745 \\
\hline Cortisol $\left(\mu \mathrm{g} \mathrm{dL}^{-1}\right)$ & $3.36 \mathrm{~b}$ & $3.36 \mathrm{~b}$ & $4.13 \mathrm{a}$ & 0.13 & 0.002 \\
\hline $\operatorname{NEFA}\left(\mathrm{mmol} \mathrm{L}^{-1}\right)$ & 0.32 & 0.37 & 0.36 & 0.01 & 0.854 \\
\hline
\end{tabular}

${ }^{1}$ Treatments: see Table 2.

${ }^{2}$ SEM: Standard error of least-squares means.

Different letters in the same row indicate significant differences among treatments (Dunnett's test, $\alpha=0.05$ ).

Table 4. Effect of treatment on plasma metabolites throughout the lactation period.

\begin{tabular}{|c|c|c|c|c|c|}
\hline & \multicolumn{3}{|c|}{ Treatment $(\mathrm{n}=10 \text { per treatment })^{1}$} & \multirow[b]{2}{*}{$\mathrm{SEM}^{2}$} & \multirow[b]{2}{*}{$P$-value } \\
\hline & $\mathrm{IND}+\mathrm{CH}+\mathrm{C}$ & $\mathrm{IND}+\mathrm{W}+\mathrm{C}$ & $\mathrm{GR}+\mathrm{C}$ & & \\
\hline Glucose $\left(\mathrm{mg} \mathrm{dL}^{-1}\right)$ & $66.89 \mathrm{~b}$ & $67.68 \mathrm{ab}$ & $72.01 \mathrm{a}$ & 0.89 & 0.021 \\
\hline Lactate $\left(\mathrm{mg} \mathrm{dL}^{-1}\right)$ & 49.47 & 43.11 & 43.45 & 1.65 & 0.851 \\
\hline $\mathrm{CK}\left(\mathrm{U} \mathrm{L}^{-1}\right)$ & 191.32 & 175.32 & 189.70 & 10.65 & 0.743 \\
\hline Cortisol $\left(\mu \mathrm{g} \mathrm{dL} \mathrm{L}^{-1}\right)$ & $2.04 \mathrm{~b}$ & $1.30 \mathrm{~b}$ & $2.99 \mathrm{a}$ & 0.16 & 0.006 \\
\hline NEFA (mmol L-1) & $0.15 \mathrm{~b}$ & $0.32 \mathrm{a}$ & $0.35 \mathrm{a}$ & 0.05 & 0.036 \\
\hline
\end{tabular}

${ }^{1}$ Treatments: see Table 2.

${ }^{2}$ SEM: Standard error of least-squares means.

Different letters in the same row indicate significant differences among treatments (Dunnett's test, $\alpha=0.05$ ). 
The total VFA concentration and individual ratios of VFAs were similar in the three treatments and did not appear to be influenced by particle size. Similar results have been reported by Asadi et al. (2009) and Zhao et al. (2011). Numerical differences indicate a lower acetate/propionate ratio in diets with a smaller particle size. Thus, working with goats, Zhao et al. (2011) concluded that diets high in physically effective fiber tend to increase the molar ratio of propionate and decrease that of butyrate. Le Liboux et al. (1999) found that diets consisting of whole dehydrated alfalfa pellets, as opposed to chopped alfalfa, reduce the molar ratio of acetate and increase that of propionate and valerate in cattle.

\section{Plasma metabolites}

Ewes in the GR $+\mathrm{C}$ treatment group had elevated levels of several stress-related plasma metabolites (glucose, cortisol and NEFAs) during lactation, which may indicate that grazing sheep are subject to increased stress due to handling (being shepherded in and out of the pens, interaction with sheepdogs and bad weather) compared to sheep that always live indoors regardless of the type of feed used $(\mathrm{IND}+\mathrm{CH}+\mathrm{C}$ or $\mathrm{C}+\mathrm{IND}+\mathrm{W})$.

Comparing the content of these plasma metabolites in sheep under different stress conditions, different researchers have found that blood values of these indicators may increase immediately after the stressor but then tend to decrease such that differences between animals not subjected to the stress are trivial. Comparing different types of stress in goats, Kannan et al. (2007) found that there was no difference in the plasma concentration of CK and NEFAs, and they found that the difference in glucose disappears within 24 $\mathrm{h}$ after the cause of stress. Similar results have been obtained in previous work by Galipalli et al. (2004).
In sheep, Zimerman et al. (2013) found that exercising lambs prior to slaughter had no effect on plasma indicators and that subjecting the lambs to barking dogs for 5 min produced a significant increase in blood cortisol levels. Knowles et al. (1995) found that transportation and food deprivation in sheep for a period of $24 \mathrm{~h}$ resulted in increased concentrations of NEFAs. This result was similar to that found by Kannan et al. (2002), who evaluated food restriction as a stressor.

In our study, the cause of stress evaluated was the type of accommodation (captive vs. traditional grazing), which can be considered a constant or chronic source of stress to which the animals can grow accustomed. Thus, we concluded that measuring this type of stress by comparing different levels of plasma metabolites may not be the most appropriate method and that it may be necessary to use methods that compare behaviors (e.g., the Welfare Quality ${ }^{\circledR}$ protocol, 2009. Consortium, Lelystad, Netherlands) to assess animal welfare. Moreover, no differences have been found among various production parameters when comparing the different treatment groups (Miguel et al., 2011). Therefore, the different levels of stress, if any existed, did not affect the final outcome.

We observed that the levels of glucose, lactate and $\mathrm{CK}$ in sheep during lactation were higher compared to those evaluated during the production cycle, thereby leading us to conclude that the acute stress of milking (e.g., separation from their lamb and injection of oxytocin) may cause an increase in these plasma metabolites.

Feeding Ojalada ewes a TMR with small particle size (chopped straw vs. whole straw) decreased the $\mathrm{pH}$ and $\mathrm{NH}_{3}-\mathrm{N}$ concentration in the rumen but did not influence the total VFA concentration or individual VFA ratios in the rumen. Furthermore, housing the ewes indoors throughout the production cycle and providing either TMR diet did not increase the plasma content of the measured stress indicators. 


\title{
Resumen
}

\begin{abstract}
J.A. Miguel, J.L. Calvo, J. Ciria y B. Asenjo 2015. Efecto del sistema de alimentación y alojamiento sobre algunos parámetros del rumen y metabolitos plasmáticos indicadores de estrés en ovejas de la raza autóctona española Ojalada. Cien. Inv. Agr. 42(1): 65-73. Para producir corderos de raza Ojalada, alimentados hasta las 5 semanas únicamente con leche de la madre, se compararon tres sistemas de alimentación: a) ovejas estabuladas y alimentadas con paja molida suplementada con concentrado preparado y distribuido mecánicamente $(\mathrm{IND}+\mathrm{CH}+\mathrm{C})$, ración integral; b) ovejas estabuladas y alimentadas con grandes pacas de paja suplementada con concentrado $(\mathrm{IND}+\mathrm{W}+\mathrm{C})$, ración integral; y c) ovejas en pastoreo suplementadas con concentrado $(\mathrm{GR}+\mathrm{C})$, grupo control. Se controlaron algunos parámetros relacionados con la fermentación ruminal $\left(\mathrm{pH}, \mathrm{NH}_{3}-\mathrm{N}\right.$, ácidos grasos volátiles) en 40 ovejas durante un ciclo productivo, y la concentración en plasma de algunos metabolitos relacionados con el estrés (glucosa, lactato, creatinina fosfato, cortisol y ácidos grasos no esterificados (NEFAs)) en un ciclo productivo y también en 10 ovejas durante la fase de lactación (5 semanas). Las ovejas alimentadas con una ración con forraje entero (IND+W+C y GR+C) presentaron mayor contenido en $\mathrm{NH}_{3}-\mathrm{N}$ y mayor contenido total de ácidos grasos volátiles (VFA), aunque en ningún caso se encontraron diferencias en el ratio acetato/propionato con las ovejas del tratamiento IND $+\mathrm{CH}+\mathrm{C}$. Se encontró para todo el ciclo productivo que las ovejas en pastoreo tuvieron mayor concentración de glucosa y cortisol, siendo también superior para este tratamiento la concentración de NEFAs cuando se evalúa el periodo de lactación. El tamaño de partícula en las raciones de ovejas alimentadas con una ración única y mecanizada influye en la concentración de $\mathrm{NH}_{3}-\mathrm{N}$ y VFA del rumen, aunque el mantenerlas cerradas durante un ciclo productivo y durante el periodo de lactación, no incrementó el contenido en plasma de los indicadores de estrés evaluados.
\end{abstract}

Palabras clave: Paja de cebada, ovejas, pastoreo, raza autóctona.

\section{References}

AOAC-Official Methods of Analysis. 1999. Official methods of analysis, $16^{\text {th }}$ ed. Association of Official Analytical Chemists International, Maryland, USA.

Asadi, A., G.R. Ghorbani, M. Alikhani, H.R. Rahmani, A. Teimouri, and K.H Südekum. 2009. Effects of lucerne particle size and source of dietary carbohydrates on in situ degradation and ruminal variables in sheep. Czech. J. Anim. Sci. 54:277285.

Azizi-Shotorkhoft, A., J. Rezaei, and H. Fazaeli. 2013. The effect of different levels of molasses on the digestibility, rumen parameters and blood metabolites in sheep fed processed broiler litter. Anim. Feed Sci. Technol. 179:69-76.

Broderick, G.A., and J.H. Kang. 1980. Automated simultaneous determination of ammonia and total amino acids in ruminal fluid and in vitro media. J. Dairy Sci. 63:64-75.

Calberry, J.M., J.C. Plaizier, M.S. Einarson, and B.W. Mcbride. 2003. Effects of replacing chopped alfalfa hay with alfalfa silage in a total mixed ration on production and rumen conditions of lactating dairy cows. J. Dairy Sci. 86:3611-3619.

Casasús, I., A. Bernués, A. Sanz, D. Villalba, J.L. Riedl, and R. Revilla. 2007. Vegetation dynamics in Mediterranean forest pastures as affected by beef cattle grazing. Agric. Ecosyst. Environ. 121:365-370.

Einarson, M.S., J.C. Plaizier, and K.M. Wittenberg. 2004. Effects of barley silage chop length on productivity and rumen conditions of lactating dairy cows fed a total mixed ration. J. Dairy Sci. 87:2987-2996.

Galipalli, S., K.M. Gadiyaram, B. Kouakou, T.H. Terrill, and G. Kannan. 2004. Physiological re- 
sponses to preslaughter transportation stress in Tasco-supplemented Boer Goats. S.A.J. Anim. Sci. 34:92-94.

Goetsch, A.L., and M.L. Galyean. 1983. Influence of frequency of feeding on passage of fluid and particulate markers in steers fed a concentrate diet. Can. J. Anim. Sci. 63:727-730.

Hedlund, P.B., and J.G. Sutcliffe. 2007. The 5-HT7 receptor influences stereotypic behavior in a model of obsessive-compulsive disorder. Neuroscience Letters 414:247-251.

INRA. 2007. Alimentation des bovis, ovins et caprins. Besoins des animaux-valeurs des aliments. Éditions Quae, Versailles Cedex. Versailles, France. 294 pp.

Kannan, G., T.H. Terril, B. Kouakou, O.S. Gazal, S. Gelaye, E.A. Amoah, and S. Samaké. 2000. Transportation of goats: effects on physiological stress responses and live weight loss. J. Anim. Sci. 78:1450-1457.

Kannan, G., T.H. Terrill, B. Kouakou, S. Gelaye, and E.A. Amoah. 2002. Simulated preslaughter holding and isolation effects on stress responses and live weight shrinkage in meat goats. J. Anim. Sci. 80:1771-1780.

Kannan, G., T.H. Terrill, B. Kouakou, and S. Galipalli. 2007. Blood metabolite changes and live weight loss following brown seaweed extract supplementation in goats subjected to stress. Small Rum. Res. 77:228-234.

Knowles, T.G., S.N. Brown, P.D. Warriss, A.J. Phillips, S.K. Dolan, P. Hunt, J.E. Ford, J.E. Edwards, and P.E. Watkins. 1995. Effects on sheep of transport by road for up $24 \mathrm{~h}$. Vet. Rec. 136:431-438.

Le Liboux, S., and J.L. Peyranud. 1999. Effects of forage particle size and feeding frequency on fermentation patterns and sites and extent of diges- tion in dairy cows fed mixed diets. Anim. Feed Sci. Technol. 76:297-319.

Miguel, J.A., J.L. Calvo, J. Ciria, and B. Asenjo. 2011. Effect of feeding system on live weight, reproductive performance, milk yield and composition, and the growth of lambs in native Spanish Ojalada sheep. Spanish J. Agr. Res. 9:769-780.

Pereira, E.S., I.Y. Mizubuti, A.B.S. Villarroel, S.M.P. de Oliveira, and P.G. Pimentel. 2009. Ruminal variables in steers fed with Tifon 85 (Cynodon spp) hay with different particle sizes. SeminaCiencias Agrarias 30:243-250.

Sevi, A., M. Albenzio, G. Annicchiarico, M. Caroprese, R. Marino, L. Taibi, A. Muscio, and S. Dell'Aquila. 2001. Effects of solar radiation and Keeling time on behaviour, immune response and production of lactating ewes under high ambient temperature. J. Dairy Sci. 84:629-640.

Van Soest, P.J. 1994. Nutritional Ecology of the Ruminant, $2^{\text {nd }}$ ed. Cornell Univ. Press, Ithaca, NY, USA. $476 \mathrm{pp}$.

Van Soest, P.J., J.B. Robertson, and B.A. Lewis. 1991. Methods for dietary fibre, neutral detergent fibre and non-starch polysaccharides in relation to animal nutrition. J. Dairy Sci. 74:3583-3597.

Yang, W.Z., and K.A. Beauchemin. 2005. Effects of physically effective fiber on digestion and milk production by dairy cows fed diets based on corn silage. J. Dairy Sci. 88:2709-2720.

Zhao, X.H., T. Zhang, M. Xu, and J.H. Yao. 2011. Effects of physically effective fiber on chewing activity, ruminal fermentation, and digestibility in goats. J. Anim. Sci. 89:501-509.

Zimmerman, M., E. Domingo, G. Grigioni, H. Taddeo, and P. Willems. 2013. The effect of preslaughter stressors on physiological indicators and meat quality traits on Merino lambs. Small Rum. Res. 111:6-9. 
